\title{
Praktikeres risikovurderinger: brugen af risikofaktorer i forebyggelsen af ungdomskriminalitet ${ }^{1}$
}

\author{
Morten Ejrnoes, mag.scient.soc, lektor emeritus AAU og Merete \\ Monrad, PhD, lektor $A A U^{2}$
}

\begin{abstract}
Social work practitioners support vulnerable children and youth who have problems or are at risk of developing problems. Increasingly, politicians and authorities are emphasizing the role of early crime prevention in social work and the role of risk factors in crime prevention.

However, there has not been a focus on how practitioners actually estimate the risk of a young person being apprehended as a first-time offender. We study practitioners' risk assessments through three vignettes. The vignettes have been constructed using register-and survey-based research on the association between youth crime and a diversity of risk factors. The vignettes are thereby constructed to allow a comparison between the risk assessments of practitioners and the actual risk as demonstrated by the data. The study utilizes a sample of 312 health visitors, teachers (including nursery school teachers) and social workers.

The results indicate that practitioners grossly overestimate the risk of apprehension for first-time offences in all three vignettes. The average assessment of the risk is approximately 50 percentage points higher than the actual calculated risk. Furthermore, there is a large variation in the risk assessments given by dif-
\end{abstract}

1. Title in English: Practitioners' risk assessments: the application of risk factors in the prevention of youth crime

2. Resultaterne i undersøgelsen stammer fra projektet: Professionelles faglige risikovurderinger, der er udført af Ida Skytte Jakobsen, Liv Tine Mayland Lyngholm, Morten Ejrnæs, Randi Riis Michelsen, Cecilie K. Moesby-Jensen og Merete Monrad fra henholdsvis UCLillebælt og Aalborg Universitet. Undersøgelsen er finansieret af Socialstyrelsen, som vi takker for støtten. Vi vil dernæst takke de fire medvirkende kommuner og især medarbejderne, der har deltaget i projektet. Vi har under udarbejdelsen af artiklen fået værdifulde kommentarer til tidligere udkast fra projektgruppens øvrige deltagere samt Annick Prieur, Tanja Dall, Dorte Caswell og Rune Holst Scherg. Endelig vil vi takke de to anonyme fagfællebedømmere for deres kommentarer. 
ferent practitioners. Moreover, practitioners associate terms such as "high risk" with very different probabilities of crime.

\section{Keywords}

Practitioners, risk assessment, risk, debut crime, vignette method

Praktikere, risikovurdering, risiko, kriminel debut og vignetmetode

\section{Indledning}

Inden for forskningen i ungdomskriminalitet har man forsøgt at identificere risikofaktorer, der er korreleret med senere kriminalitet (se fx Christoffersen et al. 2011; Olsen, Dahl og Poulsen 2016; Østergaard et al. 2015). Også fra myndighedernes side er der en stor interesse $i$ at afklare, hvilke faktorer $i$ børn og unges livsvilkår der er forbundet med risiko for senere kriminalitet, således at man tidligt kan identificere de grupper af børn og unge, som kunne have gavn af forebyggende foranstaltninger (se fx Socialstyrelsen 2017). Praktikere i velfærdsstatens frontlinje forventes at være opmærksomme på disse risikofaktorer og kunne lave risikovurderinger i det forebyggende arbejde med børn og unge.

Der er i de seneste år blevet fokuseret meget på ungdomskriminalitetsbekæmpelse, og i den forbindelse er risikovurderinger kommet til at spille en særlig central rolle. I stigende grad er der blevet sat fokus på, hvordan man kan forebygge kriminalitet gennem øget opmærksomhed på risikofaktorer (se fx argumentationen vedr. parallelsamfund i 2018, Regeringen (2018) og den nye lov om bekæmpelse af ungdomskriminalitet, Lov nr 1705 af 27/12/2018). Samlet set har praktikeres risikovurderinger således fået større betydning for iværksættelse af sanktioner og andre indgreb.

Praktikere som pædagoger, lærere, sundhedsplejersker og socialrådgivere spiller dermed en rolle i det kriminalitetsforebyggende arbejde i forhold til at identificere de børn og unge, som er i risiko for at begå kriminalitet. Fordi det ikke er entydigt, hvornår der foreligger risiko for at begå kriminalitet, har praktikere et rum for skøn, når de foretager risikovurderinger. Det gælder i særlig grad gråzonesager, hvor lovgivningen ikke klart foreskriver, hvad der skal ske (MaynardMoody og Musheno 2003: 93). Praktikeres faglige skøn har betydning for, hvilke indsatser der sættes i værk over for hvilke børn og unge. I denne sammenhæng har Lipsky (1980) argumenteret for, at frontlinjemedarbejderne i implementeringen af politik også medierer og transformerer den. Selv om frontlinjemedarbejdernes vurderinger og opfattelser ikke har betydning for den formelle politikudformning, kan de få betydning for policyleveringen. Det kriminalitetsforebyggende arbejde er nemlig ikke alene afhængig af lovgivningen, men også af, hvor- 
dan frontlinjemedarbejdere omsætter lovgivningen i arbejdet med de enkelte sager. Det er derfor væsentligt at få indblik i frontlinjemedarbejdernes faglige skøn (se også Maynard-Moody og Musheno 2003; May og Winter 2009).

Det er i den sammenhæng relevant at sætte fokus på frontlinjemedarbejderes vurdering af risikoens størrelse, fordi der er nogle særlige vanskeligheder forbundet med vurderinger af denne type. Tversky og Kahneman (1974) argumenterer således for, at når man skal vurdere risikoen for, at en hændelse vil indtræffe, bruger man intuitivt nogle heuristikker, der reducerer kompleksiteten, men som samtidig kan lede til systematisk skævvridning. Man vil bl.a. fokusere på, om en beskrivelse minder om en stereotyp knyttet til hændelsen, snarere end at bruge viden om hvor udbredt hændelsen er (fx hvor udbredt ungdomskriminalitet er). Desuden vil man typisk ikke tage højde for, om hændelsen overhovedet kan forudsiges ud fra de oplysninger, der er fremlagt (Tversky og Kahneman 1974). Og når det handler om risikofaktorer og debutkriminalitet, ved vi, at forudsigeligheden er ekstremt lav, selv for højrisikogrupper. De almen menneskelige heuristikker skaber en bias, som det er vigtigt at være opmærksom på, når man pålægger praktikere at foretage risikovurderinger. Disse heuristikker kan nemlig indebære en skævvridning, hvor risikoen systematisk overdrives, væsentlige oplysninger overses, og forbehold i forhold til de tilgængelige oplysninger ikke overvejes.

Med den øgede vægt på risikofaktorer og risikovurderinger i det kriminalitetsforebyggende arbejde er det nu særlig vigtigt, at praktikere i velfærdsstatens frontlinje har en nuanceret forståelse af risiko og risikoens størrelse og kender til begrænsninger ved anvendelse af risikovurderinger som udgangspunkt for forebyggende arbejde. På den baggrund vil vi i denne artikel belyse praktikeres opfattelse af risiko for debutkriminalitet. Vi vil sætte fokus på praktikeres vurderinger af risikoens størrelse. Og vi vil sammenligne praktikeres vurderinger af risikoens størrelse med forskningsbaseret viden om risikoens størrelse. Vi er nemlig interesseret $\mathrm{i}$, hvordan praktikere, der møder et bredt udsnit af børn og unge, bedømmer risikoen for påbegyndelse af en kriminel løbebane, fordi det er disse praktikere, som skal afgøre, hvorvidt de bør være bekymrede for fremtidig kriminalitet og fx underrette kommunen eller indlede et samarbejde med en SSP-medarbejder.

\section{Eksisterende forskning i praktikeres risikovurderinger}

En omfattende litteratur diskuterer praktikeres vurdering af risikoen for tilbagefald til kriminalitet (recidiv) blandt tidligere dømte. Hart et al. (2007) påpeger, at praktikeres risikovurdering uden anvendelse af et instrument/standardiseret skema har vist sig at være upræcis både i forhold til den faktiske risiko, som den kan 
beregnes på baggrund af eksisterende forskning, og i den forstand, at der er stor spredning i praktikernes risikovurderinger (se også Lidz et al. 1993). I denne artikel belyser vi ikke vurderingen af risikoen for recidiv, men derimod praktikeres vurdering af risikoen for kriminel debut. Vurderingen af risiko for kriminel debut, som almindelige praktikere skal foretage, adskiller sig afgørende fra vurderingen af risikoen for recidiv. For det første er den faktiske risiko for kriminel debut meget lavere, hvilket gør målrettet forebyggelse ekstremt vanskelig (Rose 1981). For det andet er unge før en kriminel debut ikke stigmatiserede, og i det kriminalitetsforebyggende arbejde bør praktikere derfor være særligt opmærksomme på, at urealistiske risikovurderinger og upræcise betegnelser som »højrisikogruppe« samt negative sanktioner kan igangsætte en stigmatisering. Stigmatiseringen og sanktionerne kan i sig selv medføre kriminalitet, hvilket bl.a. ses dokumenteret i en tvillingeundersøgelse fra England og Wales. Den viser, at både fængslinger og en mild form for sanktionering (anti-social behaviour order ASBO), som minder om de nye ungdomskriminalitetsnævns sanktionering, medførte en markant større kriminalitetshyppighed i 18 årsalderen (Motz et al. 2019). Undersøgelser af praktikeres vurderinger af risiko for kriminel debut er imidlertid sjældne, og dermed bidrager denne undersøgelse til at udfylde et videnshul.

I dansk kontekst har praktikeres vurderinger af unges risiko for kriminalitet tidligere været undersøgt med særligt fokus på betydningen af forældres kriminalitet som risikofaktor (Ejrnæs et al. 2007: 250). Dette studie satte fokus på voldskriminalitet og fandt en overdreven risikoopfattelse blandt praktikere, både i forhold til den generelle kriminalitetshyppighed og særligt kriminalitetshyppigheden blandt unge med en far, der har været dømt for vold. Vurderingen af risikoen var langt højere, når farens kriminalitet var inkluderet som risikofaktor, og forskellen mellem den faktiske risiko og praktikernes opfattelse af risikoen var også langt større, når denne risikofaktor indgik (dvs. overdrivelsen af risikoen var større). I vores studie indgår flere forskellige risikofaktorer, men som i studiet af Ejrnæs et al. (2007) sammenligner vi praktikeres risikoopfattelser med den faktiske risiko, som den kan beregnes på baggrund af forskningen på området.

\section{Metode}

Undersøgelsen er udarbejdet som en kvantitativ vignetundersøgelse. I vignetundersøgelser konstruerer man korte casebeskrivelser (vignetter), der danner udgangspunkt for spørgsmål (Ejrnæs og Monrad 2012). I denne undersøgelse ønsker vi at sammenligne praktikeres risikovurderinger med opgørelser af den faktiske risiko for kriminalitet for unge berørt af bestemte risikofaktorer. Vignetterne rummer derfor beskrivelser af unge, der er udsat for forskellige risikofaktorer. Ud 
over spørgsmål om risiko for kriminalitet er der spørgsmål om risiko for depression, kontanthjælp og manglende ungdomsuddannelse. I denne artikel analyserer vi dog kun de tre vignetter omkring kriminalitet. Respondenterne er blevet bedt om at vurdere, hvad risikoen er, for at den beskrevne person bliver anholdt, sigtet eller varetægtsfængslet inden for et år. Vignetterne er baseret på forskning i risikofaktorer, således at vignetterne indeholder præcis de samme risikofaktorer, der har indgået i dansk forskning. Studiet er altså designet således, at vi kan sammenligne praktikernes vurderinger af risikoens størrelse med den faktiske størrelse på risikoen, som den fremgår af forskning på området.

Det er dog ikke en enkel opgave at opgøre den faktiske risiko for kriminalitet, for der er bl.a. betydelige mørketal forbundet med kriminalitet. Forskning belyser typisk kriminalitet igennem offerundersøgelser, selvrapporteringsundersøgelser eller registerundersøgelser (hvor kriminalitet politiet er blevet bekendt med registreres) (se fx Balvig 2017 for en oversigt). For at skabe et sammenligningsgrundlag mellem praktikernes risikovurderinger og den faktiske kriminalitet har vi konstrueret vignetterne på baggrund af et enkelt studie: Christoffersen et al. (2011). ${ }^{3}$ Her anvendes registeroplysninger kombineret med en interviewundersøgelse. Forfatterne tager udgangspunkt i årgang 1984 og anvender registeroplysninger fra hele årgangen kombineret med interview med 2.980 personer.

Når Christoffersen et al. beregner risikoen, anvender de regressionsanalyse på datamaterialet til at opstille en model. Modellen bruges til at beregne betydningen af hver risikofaktor (altså parametret). Modellen estimerer mere specifikt risikoen for at blive anholdt, sigtet eller varetægtsfængslet inden for et år for førstegangskriminalitet. Der indgår 10 risikofaktorer i modellen, og modellen tager hensyn til, om personen er 16, 17, 18, 19 eller 20 år (formlen for modellen fremgår af Christoffersen et al. 2011: 74, og estimaterne fremgår af Christoffersen et al. 2011: 96). I modellen beregnes den absolutte risiko, og det er den vi i artiklen kalder den beregnede risiko. Vi bruger den beregnede risiko til at sammenligne med praktikernes risikovurderinger.

Den beregnede risiko dækker altså risikoen for at begå kriminalitet som giver anledning til kontakt med politiet i form af anholdelse, sigtelse eller varetægtsfængsling. Den beregnede risiko dækker ikke al den udførte kriminalitet (som ville have større omfang), og den dækker heller ikke alene den kriminalitet som

3. Grunden til at vi ikke har anvendt flere studier er, at vi har brug for at konstruere vignetterne, så de indeholder præcis de samme risikofaktorer, som er undersøgt for at sikre sammenlignelighed med den beregnede risiko. 
giver anledning til domsfældelse (som ville have mindre omfang). I vignetterne har vi sikret sammenlignelighed med den beregnede risiko ved at spørge til risikoen for, at en person bliver »anholdt, sigtet eller varetægtsfængslet«.

Vi har i undersøgelsen taget udgangspunkt i en 17-årig dreng. I vignetterne indgår følgende risikofaktorer:

- psykisk mishandling

- fysisk vold

- forældrene er arbejdsløse

- forældrene bor ikke sammen

- er droppet ud af skolen uden afgangseksamen

- har en børnesag i en socialforvaltning

- har været indlagt på en hospitalsafdeling i forbindelse med alkohol- eller stofmisbrug

Vignetterne fremgår af Tabel 1. Vignetterne er nødt til at være meget enkle, da vi kun kender risikoen for at være udsat for nogle få centrale risikofaktorer, og de rummer kun få samtidige risikofaktorer. I vignetterne indgår kun risikofaktorer. Vi har således ikke inkluderet beskyttelsesfaktorer, og vi har ikke inkluderet information om, hvorvidt der er iværksat forebyggende foranstaltninger.

Respondenterne er altså i spørgeskemaet blevet præsenteret for vignetterne og blevet bedt om at vurdere risikoen for, at den pågældende person bliver anholdt, sigtet eller varetægtsfængslet inden for et år. Vi har bedt respondenterne om at komme med deres bedste bud på, hvad risikoen er, og vi forventer selvfølgelig ikke, at respondenterne kender den præcise risiko. Det er imidlertid interessant at analysere, om der er en tendens til, at de gætter i en bestemt retning, altså om de systematisk og markant over- eller undervurderer risikoen. Praktikernes gæt siger nemlig noget om de forestillinger, de gør sig om børn og unges chancer for at klare sig og undgå alvorlige sociale problemer. Deres forestillinger kan påvirke såvel karakteren af det forebyggende sociale arbejde som børns, unges og familiers oplevelse af mødet med praktikerne.

I undersøgelsen indgår tre vignetter, der omhandler kriminalitet (Tabel 1). Til hver vignet er der blevet stillet det samme spørgsmål (se Tabel 1 under vignet 1). Vi har valgt at bede respondenterne om at angive risiko i både procent (til sammenligning med forskningsbaseret viden) og i lukkede svarkategorier som fx høj eller lav. Undersøgelsen er gennemført som en web-baseret survey. 


\title{
Tabel 1: Vignetter og spørgsmål fra undersøgelsen
}

\begin{abstract}
Vignet 1: En dreng er blevet udsat for psykisk mishandling, og forældrene har udsat ham for fysisk vold. Den unges forældre er arbejdsløse og bor ikke sammen. Han er ikke blevet anholdt, sigtet eller varetægtsfængslet som 15 -årig eller 16-årig.

Hvor høj er risikoen for, at unge drenge med disse opvaekstforhold bliver anholdt, sigtet eller varetcegtsfangslet som 17-årige?

Svarkategorier: Meget lav, lav, moderat, høj, meget høj, ved ikke

Svarskala: Angiv risikoen i procent

Vignet 2: En dreng er droppet ud af skolen uden afgangseksamen og har en børnesag $\mathrm{i}$ en socialforvaltning. Den unge har været indlagt på en hospitalsafdeling i forbindelse med alkohol- eller stofmisbrug. Han er ikke blevet anholdt, sigtet eller varetægtsfængslet som 15-årig eller 16-årig.

Vignet 3: En dreng er droppet ud af skolen uden afgangseksamen, og forældrene har udsat ham for fysisk vold. Den unge har været indlagt på en hospitalsafdeling i forbindelse med alkohol- eller stofmisbrug. Den unges forældre er arbejdsløse og bor ikke sammen. Han er ikke blevet anholdt, sigtet eller varetægtsfængslet som 15-årig eller 16-årig.
\end{abstract}

\section{Datamateriale}

Datamaterialet blev indsamlet på faglige temadage afholdt i tre kommuner. Spørgeskemaet indgik i et fagligt udviklingsprogram med fokus på risiko og resiliens. Spørgeskemaet blev udfyldt, før det faglige udviklingsprogram for at undgå, at svarene blev farvet af indholdet $\mathrm{i}$ undervisningen.

Datamaterialet består af 312 besvarelser. Hovedparten er kvinder $(93,6 \%)$ og de fleste er 35-54 år (67,3\%). I undersøgelsen indgår flest pædagoger (43,5\%), dernæst socialrådgivere $(22,0 \%)$, sundhedsplejersker $(19,8 \%)$ og lærere $(14,4 \%)$. Deltagerne er ansat i daginstitution eller dagpleje (36,7 \%), familieafdeling $(22,5 \%)$, skole $(19,0 \%)$, sundhedspleje $(8,3 \%)$, PPR eller lignende $(5,2 \%)$, handikapafdeling (3,5\%), SFO (1,4\%) og andet (3,3\%). Ca. $20 \%$ har ledelsesfunktioner.

Respondenterne arbejder i velfærdsstatens frontlinje og er således medarbejdere, der i forskellige kontekster møder både børn og unge inden for normalområdet, og børn og unge, der befinder sig i udsatte positioner. Respondenterne arbejder ikke specifikt med kriminalitetsforebyggelse. Som praktikere møder de typisk børnene og de unge før kriminalitetsdebutten. Derfor har deres risikoopfattelser særlig betydning for det forebyggende arbejde og deres samarbejde med SSP-medarbejdere og politi. 


\section{Resultater: praktikeres vurdering af risiko for kriminalitet}

I det følgende præsenterer vi praktikernes vurdering af risikoen for at blive anholdt, sigtet eller varetægtsfængslet i de tre vignetter. Vi fokuserer dels på sammenligningen mellem praktikernes risikovurderinger og den beregnede risiko og dels på spredningen i risikovurderinger blandt praktikerne.

\subsection{Risikovurderinger og beregnet risiko}

Risikoen for anholdelse, sigtelse eller varetægtsfængsling for straffelovsovertrædelse inden for et år for en 17-årig dreng uden kendte risikofaktorer er 0,5\% (Christoffersen et al. 2011: 96-97). For en dreng, der som skitseret i vignet 1, har været udsat for psykisk mishandling, fysisk vold, og hvis forældre er arbejdsløse og ikke bor sammen, kan risikoen beregnes til 4,1 \% (Christoffersen et al. 2011: 96-97). Selv med disse meget alvorlige risikofaktorer vil 95,9 \% altså ikke blive anholdt, sigtet eller varetægtsfængslet inden for det kommende år. I vignet 2 og 3 har vi tilføjet risikofaktorer omkring uafsluttet folkeskole og misbrug af alkohol eller stoffer. Desuden nævnes der i vignet 2 en børnesag i en socialforvaltning, og i vignet 3 indgår forældrenes fysiske overgreb mod drengen. Ved en ekstrem ophobning af risikofaktorer inden for meget forskellige felter som i vignet 3 (lavt uddannelsesniveau, fysisk vold, misbrug, arbejdsløse forældre, der ikke bor sammen) kan risikoen beregnes til 17,8 \% (Christoffersen et al. 2011: 96-97). Det er bemærkelsesværdigt, at selv i en så belastet situation vil langt de fleste drenge $(82,2 \%)$ ikke komme i kontakt med det strafferetlige system inden for et år. Det er en vigtig pointe, at selv når der er en ophobning af alvorlige risikofaktorer, er det kun et fătal der i det efterfølgende år bliver anholdt, sigtet eller varetægtsfængslet for debutkriminalitet. Ophobning af risikofaktorer øger selvfølgelig risikoen, men som eksemplerne viser, betyder selv en lang række alvorlige risikofaktorer kun en begrænset absolut risiko (se også Ejrnæs et al. 2020).

Ser vi på Tabel 2, viser undersøgelsen, at praktikerne gennemgående vurderer risikoen for at blive anholdt, sigtet eller varetægtsfængslet som meget stor. Den høje vurdering af risikoen afspejler utvivlsomt, at det er meget alvorlige situationer. Måske netop af denne grund kommer praktikerne til at overvurdere risikoen for, at den unge ender i kriminalitet inden for et år. Praktikerne overvurderer gennemsnitligt risikoen i de tre vignetter med henholdsvis 49,6, 55,4 og 48,2 procentpoint, og for alle faggrupper er overdrivelsen markant. Gennemsnitligt forventer de, at mere end halvdelen af drenge i en så udsat position vil blive anholdt, sigtet eller varetægtsfængslet inden for et år, mens det faktisk er en meget lille gruppe af drenge, for hvem det vil være tilfældet (4,1 \% 7,3\% og 17,8 \%). 
Tabel 2: Praktikeres gennemsnitlige risikovurderinger $i$ de tre vignetter fordelt på faggrupper. Besvarelse af spørgsmålet: »Hvor høj er risikoen for, at unge drenge med disse opvakstforhold bliver anholdt, sigtet eller varetcegtsfaengslet som 17-årige?"

\begin{tabular}{|l|c|c|c|c|c|c|}
\hline & \multicolumn{2}{|c|}{ Vignet 1 } & \multicolumn{2}{c|}{ Vignet 2 } & \multicolumn{2}{c|}{ Vignet 3 } \\
\hline & Risikovurdering & $\begin{array}{c}\text { Antal } \\
\text { svar }\end{array}$ & Risikovurdering & $\begin{array}{c}\text { Antal } \\
\text { svar }\end{array}$ & Risikovurdering & $\begin{array}{c}\text { Antal } \\
\text { svar }\end{array}$ \\
\hline Pædagog & $59,2 \%$ & 122 & $66,5 \%$ & 124 & $69,3 \%$ & 128 \\
& {$[55,0-63,3]$} & & {$[62,6-70,5]$} & & {$[65,5-73,0]$} & \\
Lærer & $48,0 \%$ & 40 & $59,9 \%$ & 38 & $62,4 \%$ & 40 \\
& {$[40,3-55,7]$} & & {$[52,1-67,7]$} & & {$[54,6-70,1]$} & \\
Socialrådgiver & $44,6 \%$ & 66 & $57,1 \%$ & 64 & $61,2 \%$ & 68 \\
& {$[39,1-50,2]$} & & {$[52,0-62,2]$} & & {$[55,8-66,6]$} & \\
Sundhedsplejerske & $56,6 \%$ & 57 & $62,2 \%$ & 58 & $66,9 \%$ & 56 \\
& {$[51,1-62,2]$} & & {$[57,5-66,9]$} & & {$[62,1-71,6]$} & \\
\hline Total & $53,7 \%$ & 285 & $62,7 \%$ & 284 & $66,0 \%$ & 292 \\
& {$[51,0-56,4]$} & & {$[60,2-65,2]$} & & {$[63,6-68,5]$} & \\
\hline Beregnet risiko & $4,1 \%$ & & $7,3 \%$ & & $17,8 \%$ & \\
\hline
\end{tabular}

Note 1: Beregnet risiko er baseret på Christoffersen et al. 2011: 96-97.

Note 2: kantede parenteser angiver $95 \%$ konfidensinterval.

Note 3: Der er følgende statistisk signifikante forskelle (5\% niveau): I alle tre vignetter vurderer pædagoger risikoen højere end socialrådgivere. I vignet 1 vurderer pædagoger desuden risikoen højere end lærere, og sundhedsplejersker vurderer risikoen højere end socialrådgivere.

Der er statistisk signifikante forskelle imellem nogle af faggruppernes risikovurderinger (se Note 3 under Tabel 2), men forskellene er forholdsvis små i forhold til, at alle faggrupper i gennemsnit overdriver risikoens størrelse med 40 procentpoint eller mere. Resultaterne er i overensstemmelse med tidligere undersøgelser (Fuglsang 2014; Ejrnæs et al. 2007). Det mest markante fund er, at alle grupper af praktikere har en overdreven opfattelse af risikoen for, at unge begår kriminalitet på tværs af alle de tre scenarier i vignetterne. ${ }^{4}$

4. I undersøgelsen viser samme tendens sig, når det gælder risikoen for at unge indlægges med en depression eller kommer på kontanthjælp. Risikoen overdrives markant, mens risikoen for ikke at opnå en ungdomsuddannelse undervurderes (disse resultater afrapporteres i Ejrnæs et al. 2019). 


\subsection{Spredning i risikovurderinger blandt praktikere}

Som tidligere vist har praktikerne gennemgående tendens til at overvurdere risikoen for kriminalitet markant, men der er en betydelig spredning i praktikernes risikovurdering. I Figur 1 har vi kategoriseret risikovurderingerne i fem kategorier fra 0-20\% vurderet risiko og op til 81-100\% vurderet risiko. Denne kategorisering viser, at praktikerne har meget forskellige vurderinger af risikoen. Hele skalaen fra $1-100 \%$ risiko benyttes i alle tre vignetter, dog er der relativt få, der benytter skalaens yderpunkter. I alle tre vignetter placerer flest respondenter sig i kategorien 61-80 \%. I vignet 1 er risikovurderingerne primært placeret fra $21-80 \%$, mens de i vignet 2 primært ligger fra $41-80 \%$ og i vignet 3 primært ligger fra $41-100 \%$.

Figur 1: Respondenternes vurdering af risikoens størrelse i fem intervaller for hver af de tre vignetter

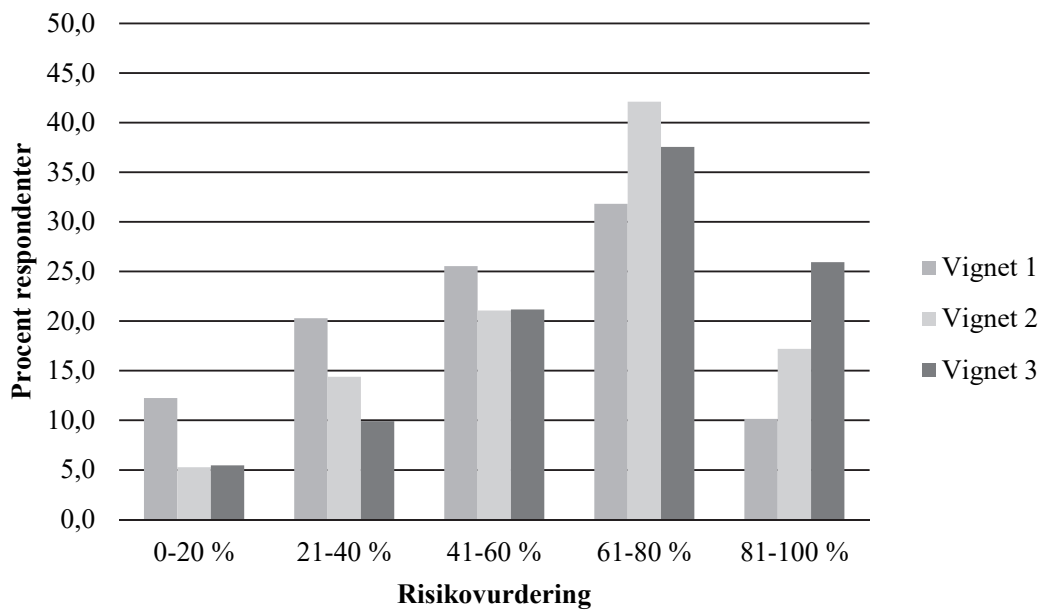

Note: standardafvigelsen for risikovurderingerne (uden kategorisering) er i vignet 1: 23,5, i vignet 2: 21,4 og i vignet $3: 21,5$.

Når vi ser på risikovurderingerne udtrykt i ord (altså i lukkede svarkategorier), viser der sig også en meget stor spredning (tabel ikke vist). Få respondenter har vurderet, at risikoen for kriminalitet er »meget lav«. I vignet 1 og 2 er der flest, der har vurderet, at risikoen er »høj«, mens der i vignet 3 er flest, der har vurderet, at risikoen er »meget høj«. Der er i vignet 1 dog også en betydelig del, som 
har vurderet, at risikoen er lav eller moderat, og i vignet 2 og 3 er der også en betydelig del, som har vurderet risikoen til at være moderat.

Sammenligner vi risikovurderingerne udtrykt $\mathrm{i}$ ord med de procentuelle risikovurderinger, så viser det sig, at der kan være meget stor forskel på, hvad respondenter betragter som henholdsvis lav og høj risiko (Figur 2). Respondenterne har meget forskellig opfattelse af, hvilken procentuel risikovurdering, der svarer til en lav, moderat eller høj risiko. Lav risiko benyttes således om en risiko på 2$35 \%$, moderat risiko benyttes om $10-75 \%$ risiko, mens høj risiko anvendes om en risiko på 5-90 \%. Besvarelserne i Figur 2 vedrører vignet 1, men mønstret er det samme for de to andre vignetter. Respondenterne kan altså anvende de samme sproglige kategorier om meget forskellige opfattelser af den procentuelle risiko.

Spørgsmålet om, hvilken procentangivelse, der repræsenterer en høj eller lav risiko, er bestemt heller ikke enkelt. Respondenter, som ikke kender til kriminalitetshyppigheder og risikoopgørelser, kan være tilbøjelige til at betragte en høj risiko som noget, der er over $50 \%$. Respondenter, der har kendskab til kriminalitetshyppigheder, ved, at en risiko på $5 \%$ er en høj eller meget høj risiko ift. en gennemsnitlig risiko på $0,5 \%$. Respondenternes forankringspunkt for risikovurderingen kan derfor være meget forskelligt pga. forskellig viden - men vignetternes indhold kan påvirke respondenterne forskelligt følelsemæssigt, hvilket også kan bidrage til den store spredning (Furnham \& Boo 2011).

Figur 2: Antal respondenter, der har betegnet risikoen som henholdsvis meget lav, lav, moderat, høj og meget høj fordelt på deres angivelse af hvor stor risikoen er i procent (vignet 1)

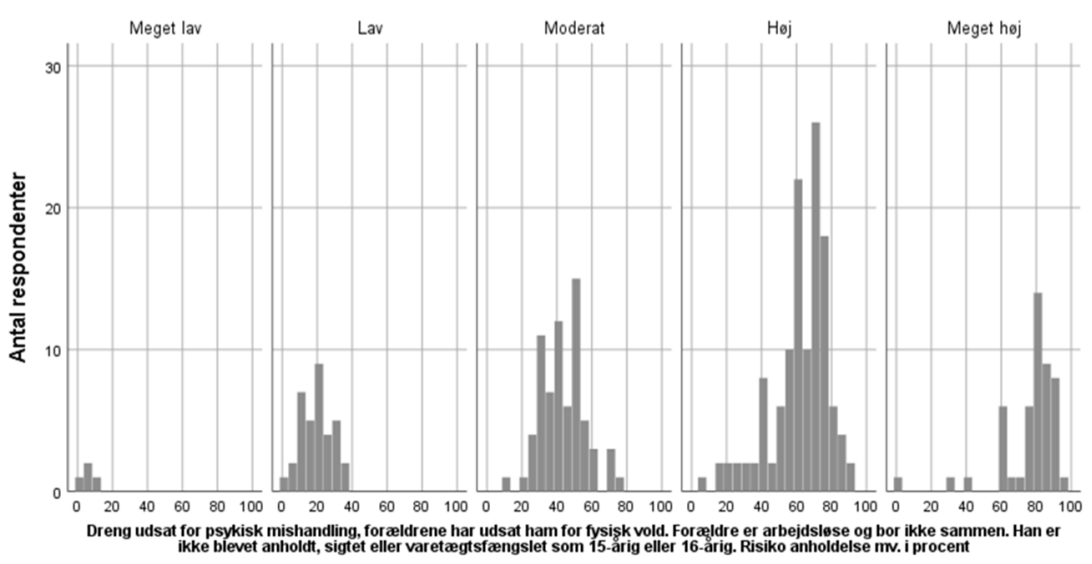


Den store spredning i risikovurderinger sammen med den forskelligartede forståelse af, hvilken sandsynlighed der er forbundet med udtryk som »lav risiko«, tydeliggør, at der blandt praktikerne ikke er en fælles forankring af risikovurderingerne og heller ikke et bare nogenlunde entydigt sprog omkring risiko. Der er således ikke noget grundlag for at kommunikere præcist om risiko $\mathrm{fx}$ i forbindelse med underretninger. Den store spredning i vurderingerne viser, at der er behov for faglige diskussioner af, hvad høj og lav risiko er, og hvilken betydning risikofaktorer skal tillægges i det socialfaglige arbejde.

\section{Diskussion af begrænsninger i undersøgelsen}

Undersøgelsen er baseret på et vignetstudie, og der er nogle generelle begrænsninger knyttet til den form for viden, man kan få ud af vignetundersøgelser, som det er værd at være opmærksom på. Vignetmetoden er egnet til at afdække holdninger, vurderinger og opfattelser, men vignetundersøgelser kan ikke umiddelbart sige noget om handlinger, altså hvad praktikere faktisk gør (Ejrnæs og Monrad 2012). Det handler bl.a. om, at når man læser en vignet, bliver et menneskes livssituation præsenteret for en, og man kan leve sig ind i beskrivelsen, men der er langt fra den individuelle envejskommunikation, som kendetegner en spørgeskemabesvarelse, til faktisk social interaktion, der er relationel, dialogisk og kropslig (Parkinson og Manstead 1993). Kritikere har således kritiseret vignetmetoden for at give kunstige eller hypotetiske svar, som ikke kan overføres til praksis (fx Faia 1980; Parkinson og Manstead 1993). Om denne kritik er berettiget afhænger i høj grad af, hvorvidt vignetterne er konstrueret, så de er realistiske (Ejrnæs og Monrad 2012; Evans et al. 2015). Det er dog væsentligt at være opmærksom på, at vignetter ikke kan afspejle faktiske situationer. Vignetter skal rumme udvalgte aspekter af en situation, så man kan studere nogle centrale elementer af en beslutningsproces eller vurdering (Evans et al. 2015).

En hyppig anført indvending imod enkle vignetter er i denne sammenhæng, at de mangler den kompleksitet og informationsrigdom, som praktikere normalt forholder sig til, og at resultaterne derfor i nogen grad er kunstige og har lav ekstern validitet. Vi har imidlertid i studiet konstrueret en længere vignet, der rummer en omfattende og nuanceret beskrivelse af en families livssituation, således at vignetten kan minde om et sagsresumé fremlagt på et tværprofessionelt møde. I denne vignet finder vi også en omfattende spredning i praktikernes risikovurderinger. Der er således ikke noget, der tyder på, at praktikernes risikovurderinger bliver mere ensartede, når de får flere informationer at forholde sig til. Det skal desuden bemærkes, at der findes studier, der dokumenterer en rimelig overens- 
stemmelse mellem praktikeres vignetvurderinger og vurderinger af virkelige borgere (se gennemgangen i Evans et al. 2015; se også Murphy et al. 1986).

Når risikovurderingerne er så høje, som de er, så kan det måske hænge sammen med, at der i vignetterne indgår mange risikofaktorer samtidig. Ser vi på undersøgelsens resultater omkring risiko for modtagelse af kontanthjælp og risiko for depression, kan vi nemlig se, at overdrivelserne er større, når der indgår mange risikofaktorer (jf. Ejrnæs et al. 2020; se også Ejrnæs, Gabrielsen og Nørrung 2007: 250). I vignetterne beder vi desuden praktikere vurdere risikoen for kriminel debut inden for et år. At skulle angive en risiko for at blive anholdt, sigtet eller varetægtsfængslet inden for en tidsramme på et år kan have gjort det vanskeligt for respondenterne at foretage en korrekt risikovurdering. Nogle respondenter kan tillige have tænkt på, at selvrapporteringsundersøgelser altid viser langt større hyppighed af kriminelle handlinger end registerundersøgelser, og de har muligvis ikke hæftet sig ved, at spørgsmålet kun vedrører kriminalitet, som har ført til anholdelse, sigtelse eller varetægtsfængsling. Endelig har nogle respondenter måske ikke lagt mærke til, at vi spørger til debutkriminalitet, og at unge, der allerede har begået kriminalitet, derfor ikke »tæller med«. De kan således have tænkt, at risikoen for alle unge med disse risikofaktorer (også dem, der allerede har begået kriminalitet) vil være meget høj. Vi har i undersøgelsen netop spurgt til den kriminelle debut, fordi et centralt problem i det kriminalitetsforebyggende arbejde er at identificere unge, som har stor risiko for at begå kriminalitet, før de debuterer som kriminelle og bliver registreret som sådan. Når de først er blevet anholdt, sigtet eller varetægtsfængslet, er de lette at identificere og målrette interventioner overfor. Her er der ikke i samme grad brug for risikofaktorer for at identificere gruppen.

Til trods for vignetmetodens begrænsninger mener vi, at vores undersøgelse giver en ny og værdifuld indsigt $i$ en gruppe praktikeres viden om risiko for debutkriminalitet og deres muligheder for at kunne kommunikere præcist om denne risiko. Vignetmetoden er særdeles velegnet til at påvise den udbredte tendens til overvurdering og spredningen i vurderingen af risikoens størrelse.

\section{Diskussion og konklusion}

I denne undersøgelse har vi sammenlignet praktikeres vurdering af risikoen for kriminel debut med risikoen beregnet på baggrund af forskning i risikofaktorer. Undersøgelsen viser, at praktikere på tværs af fag markant overvurderer risikoen for kriminalitet. Undersøgelsen viser samtidig, at praktikere har meget forskellige opfattelser af risikoen, og at det er meget forskelligt, hvilken sandsynlighed for kriminalitet, de tænker på, når de benævner risikoen som lav, moderat eller høj. 
Vi mener, at disse resultater rejser to centrale diskussioner: hvordan forskningen $\mathrm{i}$ risikofaktorer kommer mere frugtbart i spil i praksis, og hvilke konsekvenser de overdrevne risikoopfattelser kan have for praksis. Disse spørgsmål tages op i det følgende.

I undersøgelsen sammenligner vi praktikeres vurderinger af risikoens størrelse med opgørelser af den beregnede absolutte risiko for kriminalitet. Der viste sig at være en begrænset mængde danske forskningsresultater, som kunne bruges til denne sammenligning, for forskningsresultater opgøres sjældent, så den absolutte risiko fremgår eller kan beregnes. Det rejser en særskilt problematik omkring praktikeres mulighed for at anvende forskningsresultater omkring risikofaktorer. Forskning i risikofaktorer opgøres typisk som relative overhyppigheder, fx som odds ratio. ${ }^{5}$ Men praktikere har brug for indsigt i den absolutte risiko. Når forskningen kun opgør relative overhyppigheder og slet ikke formidler den absolutte risiko, så kan praktikere ikke vide om risikoen faktisk er på et højt eller lavt $n i$ veau. Fx kan forskningen vise, at en gruppe, der har været udsat for en risikofaktor, 3,6 gange så ofte begår kriminalitet sammenlignet med unge, der ikke har været udsat for denne risikofaktor. At en risiko er 3,6 gange større tyder jo på en meget høj risiko, men hvis forskellen er fra $0,1 \%$ til $0,36 \%$, så er risikoen jo stadig meget lav. For praktikere er det derfor netop kendskab til den absolutte risiko, der er af betydning. Kendskab til kriminalitetsniveauet og den absolutte risiko for kriminalitet kan tydeliggøre, at kriminalitet er et meget sjældent udfald, selv for børn og unge i stærkt udsatte positioner. Og når man kender den absolutte risiko, er det derfor lettere at undgå at overdrive betydningen af en risikofaktor.

Vores studie viser, at praktikere generelt har en stærkt overdreven risikovurdering. Forskeres tilbøjelighed til at angive resultater som relative overhyppigheder bidrager ikke til at korrigere disse men snarere til at skabe eller vedligeholde overdrevne risikoopfattelser. Relative risikoopgørelser kan bidrage til en social misforståelse (Balvig og Holmberg 2014). Denne tendens forstærkes, når medier og politikere anvender og formidler resultater fra risikoundersøgelser. For at

5. Odds ratio benyttes til at angive sandsynligheden for at en hændelse ( $\mathrm{fx}$ at en person begår kriminalitet) forekommer i en gruppe sammenlignet med sandsynligheden for samme hændelse $\mathrm{i}$ en anden gruppe ( $\mathrm{fx}$ drenge og piger). Odds ratio udtrykker forholdet mellem odds for, at fx en dreng begår kriminalitet og odds for, at en pige begår kriminalitet (odds er sandsynligheden for at begå kriminalitet divideret med sandsynligheden for ikke at begå kriminalitet). Odds ratio er forholdet mellem de to gruppers odds. Odds ratio kan sammenlignes på tværs af forskellige risikofaktorer for at afgøre, hvilken risikofaktor der har størst relativ betydning, men den absolutte risiko kan ikke beregnes alene ud fra odds ratio. 
praktikere kan bruge viden om risikofaktorer til at kvalificere det faglige arbejde, er det vigtigt, at den forskningsbaserede viden om risikofaktorer formidles på en måde, så den er både relevant og lettilgængelig for praksis.

Hvis vi vender os imod betydningen af overdrevne risikoopfattelser for praksis, så kan overdrevne risikovurderinger indebære, at udsatte børn og unge mødes med en forventning $\mathrm{om}$, at de vil klare sig dårligere end, hvad forskningen kan dokumentere. Det kan påvirke deres selvbillede og tro på at kunne undgå alvorlige sociale problemer som kriminalitet. Udpegningen af højrisikogrupper kan skabe en forestilling om, at man på baggrund af sikker faglig viden med stor sandsynlighed kan forvente et negativt udviklingsforløb for et ungt menneske. Men det kan man ikke, for selv medlemmerne af en højrisikogruppe vil have langt større sandsynlighed for at undgå problemerne end at få dem (Christoffersen et al. 2011; Østergaard et al. 2015).

Vores viden, om hvad der får børn og unge til at begå kriminalitet, er vanskelig at anvende til faktisk at identificere børn og unge, som kommer til at begå kriminalitet og målrette indsatser imod dem, før de begår kriminalitet. Derfor kommer det kriminalitetsforebyggende arbejde på baggrund af risikofaktorer til at berøre mange udsatte børn og unge, som ikke kommer til at begå kriminalitet. $\mathrm{Og}$ hvis det forebyggende arbejde tager afsæt i en kategorisering eller udpegning af »risikobørn«, kan det indebære, at der rettes overdrevent negative forventninger mod børn og unge i udsatte positioner. Det er vigtigt at undgå, at disse børn og unge »sættes i bås« med børn og unge, der allerede udviser normbrydende adfærd, således at de ikke stigmatiseres og kommer til at identificere sig med unge med normbrydende adfærd og dermed blive sårbare for at blive rekrutteret til kriminelle ungdomsmiljøer.

Inden for forebyggelses- og planlægningsfeltet kan en overdreven vurdering af risikoens størrelse betyde, at man opprioriterer indsatsen i forhold til »højrisikogrupper«, der har en høj risiko i forhold til andre grupper (relativ risiko og odds ratio), selvom de stadig har en lav absolut risiko. Den ætiologiske fraktion eller præventive gennemslagskraft ${ }^{6}$ er dog som regel meget lille. Dermed er den del af problemet, man hypotetisk kan forebygge ved at sætte ind over for en eller flere risikofaktorer og fjerne virkningen af dem, også meget lille (Rose 1981). Et

6. Ætiologisk fraktion er et centralt epidemiologisk begreb, der anvendes for at kunne lave et skøn over, hvor stor en andel af fx lungekræft, man kunne undgå ved at fjerne en risikofaktor som fx rygning. Udtrykket angiver således den maksimale effekt (præventive gennemslagskraft) af en målrettet indsats mod en eller flere risikofaktorer. 
fokus på højrisikogrupper kan altså bidrage til, at det forebyggende sociale arbejde rettes mod en meget lille gruppe, således at det ikke bidrager til at reducere andelen af kriminelle særlig meget (Ejrnæs et al. 2007). Paradokset består i, at jo højere risiko, der er forbundet med at være medlem af højrisikogruppen, jo mindre andel af de potentielt problemramte vil man nå med en indsats, som koncentrerer sig om denne lille gruppe (Rose 1981). Der kan dog, når det drejer sig om meget skadevoldende kriminalitet være et stærkt ønske om at lave indsatser, som begrænser netop denne form for kriminalitet. Med udgangspunkt i den som regel meget skæve fordeling af kriminalitet på fx lovovertrædere, geografiske områder og ofre har man kunnet konstatere en koncentration af kriminalitet med meget alvorlige skadevirkninger. Sherman (2007) beskriver dette fænomen som »the power few «. Når det drejer sig om ekstreme ophobninger af skadevoldende kriminalitet, drejer det sig dog ofte kun om en meget lille del af de kriminelle, der laver omfattende og alvorlig gentagelseskriminalitet (Sherman et al. 2016). I vores undersøgelse beskæftiger vi os ikke med det fænomen, fordi vi kun har undersøgt praktikere, der primært skal lave forebyggende arbejde i forhold til børn og unge, der endnu ikke har begået kriminalitet, som de er blevet registreret for. Undersøgelsens resultater viser imidlertid, at det kunne være relevant gennem en vignetundersøgelse at undersøge vurderinger af risiko for recidiv blandt medarbejdere inden for SSP og kriminalforsorgen.

Det er vigtigt, at praktikere i det sociale arbejde har en nuanceret forståelse af risiko og kender begrænsningerne ved anvendelse af risikovurderinger som udgangspunkt for socialt arbejde. De fleste unge, der er udsat for meget alvorlige risikofaktorer, kommer nemlig ikke til at begå kriminalitet, men der er en tendens til at praktikerne tror dette. For at kvalificere praktikeres anvendelse af viden om risikofaktorer og risikoens størrelse er det nødvendigt, at forskningen i risiko for kriminalitet tilrettelægges og formidles, så den absolutte risiko, der forbundet med bestemte risikofaktorer, fremgår klart. Dernæst er det vigtigt, at praktikerne er opmærksomme på, at de vurderer risikoens størrelse meget forskelligt, og at de ofte ikke mener det samme, selvom de bruger samme sproglige udtryk om risikoen. Endelig er det vigtigt, at praktikere er opmærksomme på, at de fra forskningen kendte risikofaktorer kun har en begrænset forklaringskraft, således at de tilskyndes til at få oplysninger om både beskyttelses- og risikofaktorer, som er særegne for det enkelte barn, så de kan danne sig et kvalificeret helhedssyn. 


\section{Litteratur}

Balvig, F. (2017) Fra barndommens gade til cyberspace. København: Det Kriminalpræventive Råd.

Balvig, F., \& Holmberg, L. (2014) Flamingoeffekten- sociale overdrivelser og social pejling. København: Jurist- og Økonomforbundets Forlag.

Christoffersen, M.N., Olsen, P.S., Vammen, K.S., Nielsen, S.S., Lausten, M., \& Brauner, J. (2011) Tidlig identifikation af kriminalitetstruede børn og unge. København: SFI, 11, 34.

Ejrnæs, M., G. Gabrielsen \& P. Nørrung (red.) (2007) Social opdrift - social arv (2. udgave). København: Akademisk Forlag.

Ejrnæs, M., Jacobsen, I.S., Lyngholm, L.T.M., Michelsen, R.R., Moesby-Jensen, C.K. \& Monrad, M. (2020): Professionelle praktikeres risikovurderinger og de faktiske risici. Uden for nummer.

Ejrnæs, M., \& Monrad, M. (2012) Vignetmetoden: Sociologisk metode og redskab til faglig udvikling. København: Akademisk Forlag.

Ejrnæs, M., Jakobsen, I.S., Michelsen, R.R., Moesby-Jensen, C.K., Lyngholm, L.T.M., \& Mon$\mathrm{rad}$, M. (2019). Professionelles faglige risikovurderinger: Rapport til kommunerne.

Evans, S.C., Roberts, M.C., Keeley, J.W., Blossom, J.B., Amaro, C.M., Garcia, A.M., ... Reed, G.M. (2015) 'Vignette methodologies for studying clinicians' decision-making: Validity, utility, and application in ICD-11 field studies', International Journal of Clinical and Health Psychology, 15(2), p. 160-170. https://doi.org/10.1016/j.ijchp.2014.12.001 PMid:30487833 PMCid:PMC6224682

Faia, M.A. (1980) 'The vagaries of the vignette world: A comment on Alves and Rossi', The American Journal of Sociology, 85(4), p. 951-954. https://doi.org/10.1086/227096

Farrington, D.P. (2005) 'Early identification and preventive intervention: How effective is this strategy?', Criminology \& Public Policy, 4(2), p. 237-248. https://doi.org/10.1111/j.17459133.2005.00018.x

Fuglsang, T. (2014) SSP-samarbejdet - En undersøgelse af det tværfaglige samarbejde og risikovurderinger i arbejdet med kriminalitetstruede børn og unge. Speciale Kandidatuddannelsen i Socialt Arbejde, Aalborg Universitet.

Frydensberg, C., Ariel, B., \& Bland, M. (2019). Targeting the Most Harmful Co-Offenders in Denmark: a Social Network Analysis Approach. Cambridge Journal of Evidence-Based Policing, 3(1-2), p. 21-36. https://doi.org/10.1007/s41887-019-00035-x

Furnham, A. \& H.C. Boo (2011) 'A literature review of the anchoring effect', The Journal of Socio-Economics, 40(1), p. 35-42. https://doi.org/10.1016/j.socec.2010.10.008

Hart, S.D., Michie, C., \& Cooke, D.J. (2007) 'Precision of actuarial risk assessment instruments: Evaluating the 'margins of error' of group v. individual predictions of violence', British Journal of Psychiatry Supplement, 190(suppl. 49), p. 60-65.

https://doi.org/10.1192/bjp.190.5.s60. PMid:17470944

Lidz, C., Mulvey, E. \& Gardner, W. (1993) 'The accuracy of predictions of violence to others', JAMA, 269(8), p. 1007-1011. https://doi.org/10.1001/jama.269.8.1007. PMid:8429581

Lipsky, M. (1980) Street-level bureaucracy. Dilemmas of the individual in public services. New York: Russell Sage Foundation. https://doi.org/10.2307/1288305

LOV nr 1705 af 27/12/2018 (2018) 'Lov om bekæmpelse af ungdomskriminalitet'. https://www.retsinformation.dk/Forms/R0710.aspx?id=206275 
May, Peter J. \& Søren C. Winter (2009) 'Politicians, managers, and street-level bureaucrats: Influences on policy implementation', Journal of Public Administration Research and Theory, 19(3), p. 453-76. https://doi.org/10.1093/jopart/mum030

Maynard-Moody, S. \& Musheno, M. (2003) Cops, Teachers, Counselors. Stories from the Front Lines of Public Service. Ann Arbor: The University of Michigan Press. https://doi.org/10.3998/mpub.11924

Murphy, K.R., Herr, B.M., Lockhart, M.C., \& Maquire, E. (1986) 'Evaluating the performance of paper people', Journal of Applied Psychology, 71(4), p. 654-661. https://doi.org/10.1037/0021-9010.71.4.654

Olsen, R.F., Dahl, K.M.V., \& Poulsen, M.H. (2016) På vej mod ungdomskriminalitet: Hvilke faktorer gør en forskel i ungdommen? København: SFI.

Parkinson, B., \& Manstead, A.S.R. (1993) 'Making sense of emotion in stories and social life', Cognition and Emotion, 7(3/4), p. 295-323. https://doi.org/10.1080/02699939308409191

Regeringen (2018) 'Ét Danmark uden parallelsamfund - Ingen ghettoer i 2030'. Marts 2018. http://www.stm.dk/multimedia/2018_t_Danmark_uden_parallelsamfund.pdf

Rose, G. (1981) 'Strategy of prevention: lessons from cardiovascular disease', British Medical Journal, 282, p. 1847-1851. https://doi.org/10.1136/bmj.282.6279.1847 PMid:6786649 PMCid:PMC1506445

Socialstyrelsen (2017), 'De 50 risikofaktorer', downloadet d. 24.1 .20 fra: https://socialstyrel sen.dk/unge/kriminalitet/redskaber/problemskabende-ungegrupperinger/viden-om-born-ogunge-i-risiko/de-50-risikoindikatorer

Sherman, L.W., Bland, M., House, P., \& Strang, H. (2016) The Felonious Few vs. The Miscreant Many. Cambridge: Cambridge Centre for Evidence Based Policing.

Sherman, L.W. (2007) 'The power few: experimental criminology and the reduction of harm', Journal of Experimental Criminology, 3(4), p. 299-321. https://doi.org/10.1007/s11292-0079044-y

Tversky, A., \& Kahneman, D. (1974) 'Judgement under uncertainty: Heuristics and biases', Science, 185(4157), p. 1124-1131. https://doi.org/10.1126/science.185.4157.1124

PMid: 17835457

Østergaard, S.V., Steensgaard, A.B., Hansen, A.T., Henze-Pedersen, S., \& Østergaard, J. (2015) På vej mod ungdomskriminalitet: Hvilke faktorer i bar 